Ks. Stanislaw Piech

\title{
BISKUPI KRAKOWSCY \\ A OBSADA KATEDR WYDZIAEU TEOLOGICZNEGO UNIWERSYTETU JAGIELLOŃSKIEGO (1880-1939)
}

Odnowiony $w 1880$ r. Wydzial Teologiczny Uniwersytetu Jagiellońskiego szybko się rozwijal $\mathrm{i}$ już $\mathrm{z}$ końcem ubiegłego stulecia osiagną znacząca pozycje naukową. Ważna rolę $w$ rozwoju fakultetu odegrali biskupi krakowscy. Pratvodawstwo państwowe i kościelne przyznawalo im bowiem decydujacy głos w doborze kadry nauczajacej. Na tym tle obok harmonijnej wspólpracy biskupa $z$ Wydziałem dochodziło niekiedy do napięć, a nawet otwartego konfliktu. Nie obylo się nawet bez zatargu z rzadem. W literaturze historycznej nie poświęcono dotąd temu zagadnieniu całościowego opracowania. Jedynie częściowo sprawa tą zają się J. Kuś, dotykając zaledwie tej newralgicznej problematyki ${ }^{1}$. W niniejszym artykule, mimo ograniczonych jego rozmiarów, podjęto próbę $\mathrm{w}$ miare całościowego zarysowania roli biskupów krakowskich w obsadzie katedr Wydziału Teologicznego UJ w latach 1880-1939.

\section{W ZALEŻNOŚCI OD BISKUPA}

$\mathrm{Na}$ wydziałach teologicznych monarchii austriackiej obsada katedr byla całkowicie uzależniona od biskupa diecezjalnego. Dekret cesarski z $1850 \mathrm{r}$. postanawial, że profesorami na wydzialach i w instytutach teologicznych moga być tylko księża posiadający misję kanoniczna od biskupa diecezji, na terenie której znajdowala się uczelnia. W tym samym roku Ministerstwo Wyznań i Oświaty (WiO) określiło zasady obsady katedr. Gdy opróżniła się katedra,

1 J. Kuś, Rola abpa J. Bilczezoskiego iv rozwiqzyivaniu niektórych spraw Wydziatu Teologicznego Unizversytetu Jagiellońskiego na poczqtku XX stulecin. „Studia Lubaczoviensia”. 2:1984, s. 101-112. 
biskup ogłaszal egzamin konkursowy $w$ tych diecezjach, których potrzeby zaspokajal odnośny fakultet. Kandydaci skladali egzamin pisemny i ustny. Trzech najlepszych kolegium profesorów prezentorvalo Ministerstwu WiO. Ostateczny jednak wybór kandydata należal do biskupa, którego obowiązkiem byla troska o prawowierne przekazywanie nauki wiary i moralności oraz świadectwo przykładnego życia kaplańskiego profesorów. Jeśli biskup nie zgłaszal sprzeciwu, wówczas kandydat na wniosek ministra otrzymywal od cesarza nominację na profesora. Prawa biskupa diecezjalnego $w$ obsadzie katedr potwierdził konkordat austriacki z 1855 r. Warunki konkursu zmieniono w 1858 r. W miejsce egzaminu ustnego wprowadzono próbny wykład. Wszyscy profesorowie na wydziałach teologicznych winni byli posiadać stopień doktora teologii ${ }^{2}$. Po wprowadzeniu instytucji docentów prywatnych zaprzestano konkursów. Kandydatów na katedry typowano zazwyczaj spośród docentów.

W Polsce odrodzonej sprawę obsady katedr na Wydziale normowalo także ustawodawstwo państwowe i kościelne. Szczególowy sposób postępowania określaly ustawy o szkołach akademickich z lat 1920 i 1933³, rozporządzenie Ministra Wyznań Religijnych i Oświecenia Publicznego (WRiOP) z 1933 r. o powolywaniu profesorów i obsadzaniu opróżnionych katedr ${ }^{4}$ oraz Statut Uniwersytetu Jagiellońskiego ${ }^{5}$. Podobnie jak w okresie galicyjskim Wydział winien był uzyskać od biskupa krakowskiego zapewnienie o udzieleniu misji kanonicznej proponowanemu przez siebie kandydatowi. Kodeks Prawa Kanonicznego z 1917 r. (can. 1381) i konkordat polski z 1925 r. przyznawały bowiem miejscowemu biskupowi diecezjalnemu wielki wplyw na dobór odpowiednich kandydatów pod względem ich prawowierności doktrynalnej i wartości moralnej przez udzielenie lub odmówienie misji kanonicznej. Po ogloszeniu przez papieża Piusa XI w 1931 r. konstytucji apostolskiej „Deus scientiarum Dominus" biskup ten udzielal profesorom misji kanonicznej po uzyskaniu "nihil obstat" od Kongregacji Seminariów i Studiów Uniwersytec$\mathrm{kich}^{7}$. Profesorów mianował prezydent Rzeczypospolitej. Aktu tego dokonywal na wniosek Rady Wydziału, przyjęty przez Senat Akademicki i przedłożony

2 Die österreichischen Unitrersitïtsgesetze herausgegeben von L. Beck von Mannagetta und Carl von Kelle. Wien $1906 \mathrm{nr}$ 93, 605, 607; Zbiớ przepisóa odnaszacych się do Kościoła $i$ duchowieństion katolickiego, zestawił I. Korzeniowski. Lwów 1900, s. 189-193; H. Zschokke, Die theologischen Studien und Anstalten der katholischen Kirche in Osterreich. Wien-Leipzig 1894, 5. 92-95.

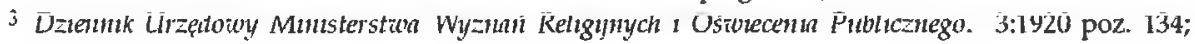
16:1933 poz. 86.

+ Tamże, 16:1933 poz. 210.

5 Statut Uniwersytetu Jagielloniskiego. Kraków 1925, § 35-42.

6 "Acta Apostolicae Sedis” (AAS) 17:1925 p. 277-278; Biblioteka Polskiej Akademii Nauk w Krakowie, Rkps 5087: Fakultety teologiczne na uniwersytetach panistwowoych.

7 "AAS" 23:1931, p. 251; H. Hoemaeker, Konstytucja Apostolskn "Deus scientianum Dominus" o wyższych studiach kościelnych. "Ateneum Kaplańskie”. 29:1932. s. 188; P. Stach, Najnowsza reforma wyższych studiów kościelnych. „Gazeta Kościelna". 38:1931, s. 494. 
mu przez Ministra WRiOP ${ }^{8}$. Zezwolenie biskupa diecezjalnego było wymagane nie tylko do nominacji profesorskiej, ale także do zatwierdzenia habilitacji, a nawet wykladów zleconych na wydziale teologicznym.

Szeroka autonomia, jaką cieszyla się Wszechnica Jagiellońska, w poważnym stopniu ksztaltowała poczucie niezależności zespołu teologów akademickich zarówno w obrębie samej uczelni, jak i wobec każdorazowego biskupa krakowskiego. Kolegium profesorów Wydzialu stało na stanowisku, że przede wszystkim ono jest odpowiedzialne za dobór i rozwój własnej kadry nauczającej. Zdaniem jego biskup krakowski mógl decydować o obsadzie katedr tylko przez udzielanie misji kanonicznej (veniam docendi). Natomiast o udzielaniu prawa wykladania (veniam legendi) mógl wypowiadać się jedynie Wydzial, oceniając kwalifikacje naukowe kandydata na katedrę. Na tym tle dochodzilo do nieporozumień, zadrażnień, a nawet długotrwalych konfliktów. Studentami fakultetu, poza nielicznymi wyjątkami, byli bowiem alumni seminarium diecezjalnego. $\mathrm{Z}$ tego względu biskupi chcieli mieć jak największy wplyw na dobór kadry nauczającej i o ile moźności starali się, jako najbardziej sobie znanych, preferować księży diecezji krakowskiej. Ten kierunek polityki personalnej biskupów krakowskich w odniesieniu do Wydziału dawał o sobie znać już na początku lat dziewięćdziesiatych ubiegłego wieku.

Kard. Albin Dunajewski w 1891 r. odmówił misji kanonicznej ks. Adamowi Kopycińskiemu, proboszczowi w Radomyślu (diec. tarnowska), bylemu profesorowi teologii pastoralnej $w$ Instytucie Teologicznym $w$ Tarnowie. Powodem odmowy była działalność polityczna ks. Kopycińskiego jako posla do Rady Państwa, trudna do pogodzenia $z$ obowiązkami profesorskimi. $W$ piśmie $w$ tej sprawie skierowanym do namiestnika Galicji Kazimierza hr. Badeniego, kardynal uskarżal się jednakże, że Wydzial na każdą opróżnioną katedrę szukał dotąd i nadal poszukuje kandydatów poza granicami diecezji krakowskiej; gdy tymczasem znajdują się już $W$ niej dość liczni księża ze stopniami uniwersyteckimi, którzy „z korzyścią dla nauki, i z większym nierównie pożytkiem niż obcy nie poczuwający się do żadnych względem diecezji obowiązków i łączności z duchowieństwem, katedry na Uniwersytecie zają́ mogli i powinni" ${ }^{9}$.

\section{KARD. JANA PUZYNY KONFLIKT Z UNIWERSYTETEM}

W sprawie obsady wakujących katedr teologii dogmatycznej i pasterskiej doszło do długotrwałego sporu kard. Jana Puzyny z Wydzialem Teologicznym UJ.

8 „Dz. Urz. Min. WRiOP” 3:1920, poz. 134; 21:1938, poz. 4; Statut UJ § 37, 43-47.

9 Archiwum Kurii Metropolitalnej w Krakowie (AKMK), Wydz. Teol. (WT), 1890-1928: KsiażęcoBiskupi Ordynariat do Namiestnictwa Galicyjskiego, Kraków 5 XII 1891, (brulion). 
Po przeniesieniu w 1899 r. na emeryturę ks. Mariana Ignacego Morawskiego TJ opróżnila się katedra dogmatyki szczególowej. Wydzial w tym samym roku przedstawił Ministerstwu na tę katedrę ks. Franciszka Gabryla, profesora filozofii chrześcijańskiej i teologii fundamentalnej w UJ. Kardynał jednak nie zgodził się na tę kandydaturę. W $1900 \mathrm{r}$. Wydział porozumiał się z ks. Franciszkiem Tessen-Węsierskim, profesorem nadzwyczajnym dogmatyki ogólnej w Uniwersytecie Wrocławskim, który wyraził chęć objęcia wakującej katedry. Ks. Tessen-Węsierski, chociaż był pochodzenia polskiego, to jednak nie władal językiem polskim, ale wykłady dogmatyki szczegółowej w UJ odbywaly się w języku hacińskim. Ministerstwo poleciło ówczesnemu dziekanowi ks. Stanisławowi Spisowi, aby porozumial sie z biskupem w sprawie wyrażenia zgody na tę kandydaturę. Kard. Puzyna jednak odmówil. W tych warunkach Wydział dnia 29 kwietnia 1901 r. zaproponował Ministerstwu ks. dra Pawla Rawskiego, kapłana diecezji przemyskiej, penitencjarza w kościele Mariackim $w$ Krakowie na stanowisko profesora nadzwyczajnego dogmatyki szczegółowej, ale $\mathrm{i}$ ten kandydat został przez Ordynariat Książęco-Biskupi odrzucony ${ }^{10}$.

Z podobnymi przeszkodami ze strony biskupa spotykały się wysilki Wydziału w celu obsadzenia katedry teologii pasterskiej. W 1899 r. po rezygnacji $z$ tej katedry ks. Józefa Sebastiana Pelczara zaproponowano Ministerstwu dnia 18 lipca 1899 r. ks. dra Józefa Caputę, wikariusza parafii Mariackiej w Krakowie. Kandydatura ta zostala przez rząd odrzucona na skutek sprzeciwu biskupa. Wydzial przynaglany przez Ministerstwo przedstawil dnia 12 października tego roku ks. dra Michala Zygulińskiego, profesora teologii pastoralnej $w$ Instytucie Teologicznym $w$ Tarnowie, jako kandydata na profesora nadzwyczajnego tego przedmiotu. Jednak i ta propozycja nie uzyskała zgody kard. Puzyny. Wtedy Wydział sam próbował w 1900 r. porozumieć się z Ordynariatem Książęco-Biskupim w sprawie ewentualnego obsadzenia tej katedry przez ks. Józefa Teodorowicza, kanonika gremialnego ormiańskiej Kapituły Metropolitalnej we Lwowie, późniejszego arcybiskupa lwowskiego tego obrządku. Po rozmowie dziekana ks. Władyslawa Chotkowskiego z kard. Puzyną i ta propozycja upadla. W dniu 18 czerwca 1901 r. przedstawiono Ministerstwu WiO kandydaturę ks. dra Karola Szczeklika, profesora teologii moralnej w tarnowskim Instytucie Teologicznym i znowis 7nstala ona odrzucona z powodu sprzeciwu biskuja krakówiskiego ${ }^{1 !}$.

10 Archiwum Uniwersytetu Jagiellońskiego (AUJ), WT 15: Protokoly z posiedzeń Rady Wydz. Teol. UJ, 23 Il 1900, 13 IV 1901; WT II 65 Wydz. Teol. UJ do Min. WiO, Kraków 29 IV 1901, 15 VI 1907; Min WiO do Dziekanatu Wydz. Teol. UJ, Wiedeń 26 VIII 1901.

11 AUJ, WT II 64: Wydz. Teol. UJ do Min WiO, Kraków 18 III, 18 VIII, 12 X 1899; Min WiO do Wydz. Teol., Wiedeń 30 IX 1899, 3 II 1900; WT II 15: Protokól z posiedzenia Rady Wydz. Teol. UJ, 23 II 1900; WT II 65: Wydz. Teol. do Min. WiO, Kraków 18 VI 1901 (brulion); Min. WiO do Wydz. Teol., Wiedeń 27 XII 1901. 
Rząd nalegal, aby katedry te zostaly wreszcie obsadzone. W tych warunkach dziekan ks. Wladysław Knapiński w styczniu 1907 r. wystosowal do Stolicy Apostolskiej specjalny memorial, w którym pisal, że Wydzial napotyka na wszelkie przeszkody ze strony biskupa $\mathrm{w}$ obsadzeniu wakujących $\mathrm{i}$ w tworzeniu nowych katedr. Przedstawieni Ministerstwu najgodniejsi i najbardziej naukowo przygotowani kandydaci na wakujace katedry nie uzyskali nominacji ze względu na veto Ordynariatu krakowskiego. Ten sposób postępowania biskupa sprawil, że inne wydzialy posiadaly po $30 \mathrm{i}$ więcej profesorów a Wydzial Teologiczny liczyl ich zaledwie sześciu. W roku bieżącym i następnym starsi przejdą na emerytury, zostanie więc dwóch lub trzech profesorów. Sytuacja ta mogłaby doprowadzić do upadku Wydzialu. Pozbawiony koniecznej liczby profesorów straci wszelki autorytet i wszelkie posiadane prawa i przywileje. Byloby to - podnosili profesorowie - wielka szkoda dla wiary i nauki katolickiej w całym narodzie ${ }^{12}$.

Kongregacja Studiów zwrócila się dnia 21 stycznia tego roku do kard. Puzyny z prośba o wyjaśnienie tej sprawy ${ }^{13}$.

Ministerstwo na skutek starań rektora UJ Kazimierza Morawskiego znowu wezwalo Wydział do obsadzenia wakujących od ośmiu lat katedr. Zostali wówczas $w$ czerwcu tego roku ponownie zaproponowani rzadowi na katedrę dogmatyki ks. Tessen-Węsierski, który obiecal w krótkim czasie nauczyć się języka polskiego, aby mógł kierować pracami studentów, a na katedrę teologii pasterskiej - ks. Caputa, wówczas już proboszcz kolegiaty św. Anny i znany kaznodzieja krakowski ${ }^{14}$.

Ks. Gabryl po swoim wyborze na rektora UJ osobiście udal się do Kardynala, przebywajacego wtedy na Bielanach, aby omówić z nim sprawę obsady obydwóch katedr. Na prośbę rektora interweniowali u niego także: Julian Dunajewski, byly minister skarbu w rzadzie austriackim, K. Morawski, prorektor U], Ludwik Ćwikliński, referent w Ministerstwie WiO oraz ks. Jan Mazanek kanonik katedralny ${ }^{15}$. Kard. Puzyna $w$ piśmie do Namiestnictwa z dnia 8 grudnia 1907 r. odrzucil obydwóch kandydatów na profesorów. Odmowę udzielenia misji kanonicznej ks. Tessen-Węsierskiemu umotywowal nieznajomością przez niego języka polskiego. Zdaniem Ordynariatu KsiążęcoBiskupiego w ogóle nie było potrzeby obsadzenia obydwóch katedr. Dogmatykę szczegółowa bowiem od pólrocza zimowego 1901/02 „z wielkim powodzeniem"wykladal ks. Szymon Hanuszek, prefekt seminarium diecezjalnego, który przygotowywal pracę habilitacyjna z tej dyscypliny. Wyklady zaś

12 AKMK, WT, 1890-1928: Wydz. Teol. UJ do Stolicy Apostolskiej, ? I 1907 (kopia).

13 Tamże, Kongregacja Studiów do kard. J. Puzyny, Rzym 21 I 1907.

14 AUJ, WT II 65: Wydz. Teol. UJ do Min. WiO, Kraków 15 VI 1907; AKMK, WT, 1890-1928: Namiestnictwo do Książęco-Biskupiego Ordynariatu, Lwów 14 VII 1907.

15 Biblioteka Jagiellońska (BJ) Rkps 8090 III, k. 197-198: ks. F. Gabryl do M. Bobrzyńskiego, Kraków, 29 V 1908. 
z teologii pastoralnej należało powierzyć ks. Janowi Krupiniskiemu, kanonikowi kapituly katedralnej, który uczyl tego przedmiotu od początku roku 1899/1900 „z nader pomyślnym wynikiem”. Zastępstwo to miało trwać aż do czasu, kiedy któryś z księży studiujących teologię na Uniwersytecie w Innsbrucku lub Rzymie nie przygotuje się należycie do objęcia tej katedry ${ }^{16}$.

Konflikt narastal. Na poczatku grudnia 1907 r. deputacja Kola Polskiego z Wiedniu zlożyła zażalenie w tej sprawie na rẹce nuncjusza apostolskiego w Austrii, abpa Granito di Beltmonte Gennaro. Interwencja ta spowodowala ożywione, $z$ polecenia papieża Piusa $X$, zainteresowanie się nią $w$ Kurii Rzymskiej. Prefekt Kongregacji Studiów kard. Francesco Satolli w liście do kard. Puzyny z dnia 11 grudnia tego roku, wspominając o tej deputacji i uskarżaniu się profesorów, że ze względu na jego sprzeciw od dluższego już czasu nie było na Wydziale żadnej nominacji, prosil o dokładne przedstawienie tej kwestii ${ }^{17}$. Kard. Puzyna w obszernej odpowiedzi z dnia 23 grudnia tlumaczyl się, że jako biskup, wyrażając swoją zgodę na nominację profesora, winien posiadać dobre rozeznanie o wartości moralnej kandydata, któremu mial powierzyć wykształcenie i wychowanie swojej młodzieży duchownej. Tymczasem księża proponowani Ministerstwu przez Wydział są mu zupełnie lub mało znani, aby mógł bez roztropnej obawy zgodzić się na ich kandydatury. Oczywiście nie odnosilo się to do księży diecezji krakowskiej, których dobrze znał. Kardynał podkreślił, że corocznie wysyla kleryków na studia teologiczne do Rzymu i Innsbrucku, aby ich przygotować jako ewentualnych kandydatów na katedry. W sprawie nieobsadzonych katedr odpowiadal̆, że zarówno teologii dogmatycznej jak i pastorainej bardzo dobrze ucza wspomniani już zastẹpcy profesorów. Zdaniem jego, istotnym podlożem skargi profesorów byla ich wola niezależności w wyborze kolegów i niechęć dopuszczania do swego grona księży bardziej oddanych biskupowi ${ }^{18}$, co w warunkach poczucia autonomii Wydzialu bylo w gruncie rzeczy prawdą.

Konflikt przybrał na sile, gdy namiestnik Galicji Alfred hr. Potocki poufnym pismem z dnia 6 stycznia 1908 r. zawiadomil Senat UJ o odmowie kard. Puzyny udzielenia misji kanonicznej kandydatom zaproponowanym rządowi przez Wydział w 1907 r. i jego woli pozostawienia nadal wymienionych zastępców na wakujacych katedrach. Namiestnik prosil o poufne wyrażenie stanowiska Senatu $\mathrm{w}$ tej sprawie ${ }^{19}$. W zwiazku $z$ tym dziekan ks. Tadeusz Gromnicki zwolal $w$ dniu 13 styczia poufne posicdzenic profesorów Wydziału, na którym jednomyślnie podtrzymano wniosek o najrychlejsze

16 AKMK, WT, 1890-1928: Książęco-Biskupi Ordynariat do Namiestnictwa, Kraków 8 XII 1907, (brulion).

17 Tamże: Kongregacja Studiów do kard. J. Puzyny, Rzym 11 XII 1907.

18 Tamże: kard. J. Puzyna do kard. F. Satolii, Kraków 23 XII 1907, (brulion). - E. Komar, Kardyntał Puzyrı. Moje wspomnienia. Kraków 1912, s. 96-99.

19 AU] S II 799: Namiestnictwo do Senatu Akad. UJ, Lwów 6 I 1908. 
powierzenie katedry dogmatyki szczególowej ks. Tessen-Węsierskiemu i katedry teologii pastoralnej - ks. Capucie.

Ks. Gromnicki w piśmie do Senatu Akademickiego z dnia 14 stycznia tego roku w sprawie obsadzenia katedry dogmatyki oznajmiał, że przedmiot ten jest wykładany w języku łacińskim. Ks. Tessen-Węsierski zaś posiada na tyle znajomości języka polskiego, "że może z latwością porozumiewać się ze słuchaczami". Profesorowie nie mogli natomast reflektować na ks. Hanuszka, ponieważ nie ogłosił dotąd żadnej pracy naukowej i nie przystąpił do habilitacji. Wydział czuł się ponad to "przymuszony"do jak najszybszego obsadzenia tej katedry, ponieważ Ministerstwo domagalo się, aby $w$ najbliższym czasie "jakaś znakomitsza siła" wykładala osobno dogmatykę traktatowa. Postulat wyczekiwania aż któryś z księży studiujacych w Innsbrucku lub Rzymie przygotuje się do objęcia katedry teologii pasterskiej był nieuzasadniony. Uczelnie tamtejsze bowiem nie byly $w$ stanie dać im formacji pastoralnej, odpowiedniej dla polskich warunków narodowych i społeczno-kulturalnych ${ }^{20}$.

W dniu 15 stycznia 1908 r. rektor ks. Gabryl zwolał Senat Akademicki w sprawie obsady katedr na Wydziale Teologicznym. Uchwalono opracować obszerny memoriał do Namiestnictwa, a odpis przesłać do Ministerstwa WiO. Przygotowaniem tego pisma zajęła się specjalna komisja, w skład której weszli profesorowie: ks. T. Gromnicki, Kazimierz Kostanecki, Kazimierz Morawski i Stanisław Wróblewski ${ }^{21}$. Memoriału tego nie udało się odnaleźć. Zachował sie jedynie nie calkiem kompletny brulion ks. Gromnickiego.

W memoriale tym Senat stwierdzal, że na skutek nieobsadzenia wakujacych od dziewięciu lat katedr zagraża Wydziałowi Teologicznemu obniżenie jego znaczenia naukowego, zwłaszcza że $w$ najbliższych latach najstarsi profesorowie przejda na emeryturę. Wyrażano przy tym obawę, że pozostawiając nieobsadzone katedry czasowym zastępcom „Wydział może zejść do poziomu szkoły fachowej i straci charakter uniwersytecki". Senat usilnie bronił stanowiska, że wybór kandydatów i ocena ich kwalifikacji naukowych należy "jedynie i wylącznie" do Wydzialu. Ze względów więc naukowych i dydaktycznych popierał kandydatury ks. Tessen-Węsierskiego na katedrę dogmatyki szczególowej i ks. Caputy na katedrę teologii pasterskiej. Senat przyznawał słuszność Wydzialowi Teologicznemu, że przy obsadzie katedr ogląda się za najlepszymi siłami naukowymi. Zasada ta, której ściśle przestrzegały pozostałe wydzialy, stanowiła podstawę postępu naukowego w Uniwersytecie. Winna ona być szczególnie zachowywana przez wydziały teologiczne, którym groziło niebezpieczeństwo łatwego zniżenia się do poziomu "szkoły diecezjalnej". Senat $w$ zupelności uznawał prawo biskupa diecezjalnego do wywierania pośredniego wpływu na obsadę katedr na Wydziale Teologicznym przez

20 Tamże: Dziekan Wydz. Teol. do Senatu Akad. UJ, Kraków 14 I 1908.

21 AUJ S II 84: Protokól z posiedzenia Senatu Akad. UJ, 15 I 1908. 
odmówienie misji kanonicznej kandydatom podejrzanym pod względem wiary i moralności. Zaznaczyl jednak, że Wydział nigdy takich osób nie proponował rządowi. $Z$ żalem podnosil, że biskup nie tylko ustawicznie sprzeciwia się kandydatom Wydzialu, ale „w ogóle obecnie uważa za niepotrzebne obsadzenie od tak dawna wakujacych katedr" 22 .

Rektor ks. Gabryl zwrócil się do Ministerstwa WiO z prośbą, aby w porozumieniu ze Stolica Apostolską umożliwil obsadę katedr wakujących już prawie od dziesięciu lat ${ }^{23}$. Minister Gustaw Marchet interweniowal w Rzymie, wyrażając duże zaniepokojenie opozycja kard. Puzyny przeciwko nominacji proponowanych kandydatów i ostrzegal, że gdy zabraknie niewielu już starych profesorów, którzy jeszcze pracują, powstanie w parlamencie ruch za zniesieniem fakultetu krakowskiego. Likwidacja zaś ta moglaby okazać się niebezpiecznym precedensem do usuwania wydziałów teologicznych $\mathrm{z}$ uniwersytetów państwowych ${ }^{24}$.

Kard. Puzyna ze swojego punktu widzenia informowal o rozwoju konfliktu pracujacych w Kurii Rzymskiej księży: Adama Sapiehę, swego późniejszego następce i Kazimierza Skirmunta, których prosił o poparcie w Kongregacji Studiów ${ }^{25}$. Kongregacja ta dnia 21 stycznia 1908 r. wezwala profesorów do podporządkowania się woli biskupa. Zalecala im, aby na przyszłość przed wyslaniem wniosku do rządu uzgadniali $z$ biskupem kandydatów na profesoró $w^{26}$. Poinformowany o tym kard. Puzyna odpisał kard Satolli, podobnie jak Namiestnictwu w dniu 8 grudnia zeszlego roku, że na katedrę dogmatyki przygotowuje się habilitant ks. Hanuszek, a z obsada katedry teologii pastoralnej należy jeszcze poczekać na któregoś z księży studiujacych za granica ${ }^{2 \pi}$.

Wydział odpowiedział Kongregacji Studiow obszernym memoriałem z dnia 10 lutego 1908 r., w którym stwierdzał, że porozumiewal się z kard. Puzyna przed przedstawieniem rządowi kolejnych kandydatów na wakujące katedry. Biskup jednak usilnie dążył do obsadzenia katedr wylącznie księżmi diecezji krakowskiej. Wydział dotychczas był otwarty - podkreślano - dla profesorów rekrutujacych się z kleru diecezjalnego i zakonnego z całego obszaru ziem polskich. Ograniczanie kadry tylko do księży jednej diecezji rodzilo obawę przekształcenia Wydziału w "szkołę czysto diecezjalna", co stałoby się wielka szkodą dla dobra nauki teologicznej i Kościoła. Profesorowie odwołując się do austriackiego prawodawstwa uniwersyteckiego podkreślali, że żadna miara

22 AUJ, WT II 52: ks. T. Gromnicki do Namiestnictwa, b.d., (brulion).

23 BJ Rkps 8090, k. 198: ks. F. Gabryl do M. Bobrzyńskiego, Kraków 29 V 1908.

2t AKMK, WT, 1890-1928: Sekretariat Stanu do Prefekta Kongregacii Studiów, Watykan 21 I 1908, (kopia).

25 Tamże: ks. K. Skirmunt do kard. J. Puzyny, Rzym 17 I 1908; ks. A. Sapieha du kard. J. Puzyny, Rzym 5 I, 15 II, 16 X 1908.

26 AUJ, WT II 289: Kongregacja Studiów do Profesorów Teologii UJ, Rzym 21 I 1908; AKMK, WT, 1890-1928, (kopia).

27 AKMK, WT, 1980-1928: kard. J. Puzyna do kard. F. Satolli, Kraków 7 II 1908, (brulion). 
nie moga proponować ks. Hanuszka na profesora. Nalegali natomiast, aby przedstawieni przez Wydzial kandydaci uzyskali misję kanoniczną ${ }^{28}$. Konflikt stal się już publicznie znany i podważal autorytet Wydziału w'śród spoleczności uniwersyteckiej. Radykalna mlodzież akademicka $w$ paździemiku 1907 r. domagała się usunięcia Wydziału Teologicznego z UJ. Demonstracje te spotęgowaly się jeszcze bardziej w 1908 r. w związku z falą protestów w imię wolności nauki, jaka przelewala siẹ przez uniwersytety monarchii po zawieszeniu przez rząd wykładów Ludwika Wahrmunda, profesora prawa kościelnego na Wydziale Prawa Uniwersytetu w Innsbrucku za jego wolnomyślne poglądy i krytykę dogmatów katolickich ${ }^{29}$. W tych warunkach nie można było dlużej bez szkody dla nauki odwlekać obsady wakujących katedr.

W lutym 1908 r. z ramienia rządu osobiście interweniowal u kard. Puzyny wspomniany L. Ćwikliński, niestety bezskutecznie. Kardynał oświadczył mu, że nie dopuści do walki narodowościowej na Wydziale przez mianowanie profesora nie umiejącego po polsku. Nie ustąpi też z przyslugujacego mu prawa, że Wydział przed przedłożeniem Ministerstwu listy kandydatów na profesorów winien porozumicć siç $\mathrm{z}$ biskupem 30 .

Kongregacja Studiów zaproponowała kard. Puzynie zasugerowanie Wydziałowi, aby zgodził się na ks. Hanuszka jako kandydata na katedrę dogmatyki a na katedrę teologii pastoralnej pozostawił biskupowi wybór pomiędzy ks. Tessenem-Węsierskim a ks. Caputą ${ }^{31}$. Kardynal z zadowoleniem przyjąl propozycje prefekta Kongregacji w sprawie dogmatyki. Zdecydowanie natomiast odrzucil sugestię $w$ kwestii obsady drugiej katedry. Teologia pasterska wykładana $w$ języku ojczystym wymagała koniecznej znajomości życia i obyczajów społeczeństwa polskiego. Ks. Tessen-Węsierski nie posiadal jednak odpowiedniej znajomości języka i kultury polskiej. Ks. Caputa natomiast został odrzucony ze względu na swoje konfliktowe usposobienie i brak „poważnego dziela" opublikowanego drukiem. Biskup znowu zaznaczyl, że nie ma naglącej potrzeby obsady tej katedry, ponieważ ks. Krupiński dobrze uczy kleryków. Stan taki może być więc utrzymany dopóki nie znajdzie się odpowiedniego kandydata ${ }^{32}$. Za kilkanaście dni kard. Puzyna zaproponowal Kongregacji

28 AUJ, WT II 61: Kolegium Profesorów Wydz. Teol. UJ do Kongregacji Studiów, Kraków 10 II 1908, (kopia).

29 S. Konarski, "Zimmemninda” w Uniwersytecie Jagielloniskim (1910-1911). W: H. Dobrowolski, M. Francić, S. Konarski, Postępowe tradycje młodzieży akademickiej a Krakoivie. Kraków 1962, s. 136-137.

30 AKMK, WT, 1980-1928: kard. J. Puzyna do ks. A. Sapiehy, Kraków 22 II 1908, (brulion); BJ Rkps 8090, III k. 148-149: L. Ćwikliński do M. Bobrzyńskiego, Wiedeń 22 V 1908.

31 AKMK, WT, 1890-1928: Kongregacja Studiów do kard. J. Puzyny, Rzym 1 III 1908.

32 Tamże: Kard. J. Puzyna do kard F. Satolli, Kraków 5 III 1908; Kard. J. Puzyna do ks. A. Sapiehy, Kraków IV 1908, (bruliony). 
kandydaturę ks. Józefa Kaczmarczyka, docenta Pisma św. NT i wicerektora seminarium diecezjalnego na katedrę teologii pasterskiej ${ }^{j 3}$.

Kongregacja Studiów w piśmie z dnia 8 kwietnia 1908 r. skierowanym do Wydzialu sugerowala mu na katedrę dogmatyki ks. Hanuszka, któremu zamiast rozprawy naukowej mogłaby być zaliczona sicdmioletnia praca dydaktyczna, i ks. Kaczmarczyka na profesora teologii pastoralnej ${ }^{j 3}$.

Rektor Uj ks. Gabryl zwrócil się do namiestnika Galicji Michała Bobrzyńskiego z prośba o interwencję u kard. Puzyny w sprawie zażegnania wreszcie tego gorszącego sporu ${ }^{35}$. Ministerstwo zaś znowu wywarlo nacisk na Wydzial w celu ostatecznego obsadzenia wakujących katedr. Profesorowie przedstawili kandydatury: ks. Tadeusza Trzcińskiego, dogmatyka, bylego profesora w Seminarium Duchownym $w$ Gnieźnie, a ivtedy proboszcza w Walkowie, na katedrę dogmatyki i znowu ks. Caputę na katedrę teologii pastoralnej ${ }^{36}$. Dnia 14 lipca 1908 r. Wydzial w obszernym, rzeczowo udokumentowanym memoriale do Kongregacji Studiów wykazal, że ze względów naukowych nie może proponować rządowi ani ks. Hanuszka, ani ks. Kaczmarczyka ${ }^{37}$. Kard. Puzyna dnia 22 września tego roku odpowiedzial Namiestnictwu, że nie udzieli misji kanonicznej księżom Trzcińskiemu i Capucie ${ }^{38}$.

Konflikt przedłużal się a wysiłki mediacyjne Kongregacji podejmowane $z$ odległego Rzymu nie odnosily sukcesu. W tych warunkach zdecydowano się w Kurii Rzymskiej na krok bez precedensu.

Papież Pius X dla ostatecznego rozwiazzania tego konfliktu ustanowił dnia 7 października 1908 r. abpa Józefa Bilczewskiego, metropolitę lwowskiego obrz. lac., bylego profesora i rektora tamtejszego uniwersytetu, swoim legatem z najrozleglejszymi uprawnieniami do obsadzenia wakujacych i majacych powstać nowych katedr na Wydziale Teologicznym UJ. Kongregacja Studiów sugerowała apbowi Bilczewskiemu, aby w rozwiązaniu tego trudnego i drażliwego sporu pominął zarówno kandydatów biskupa krakowskiego jak i Wydziału i wybrał calkiem innych. Proponowała mu następujacych księży: Kazimierza Waisa, profesora filozofii w Seminarium Duchownym w Przemyślu, Macieja Sieniatyckiego, profesora teologii dogmatycznej szczegółowej w Uniwersytecie Lwowskim, Ignacego Warmińskiego, profesora

33 Tamże: Kard. J. Puzyna do kard F. Satolli, Kraków 16 III 1908, brulion.

34 Tamże: Kongregacja Studiów do Kolegium Teologów UJ, Rzym 8 IV 1908; BJ Rkps 8090 III, k. 190 . ks. F. Gabyi du iví. Dubrzyńskiego, Ḱraków 29 V 1900.

35 BJ Rkps 8090 Ill, k. 197: ks. F. Gabryl do M. Bobrzyńskiego, Kraków 29 V 1908.

36 Archiwum Glówne Akt Dawnych w Warszawie (AGAD), MWiO 44 u: Kolegium Profesorów Wydz. Teol. UJ do Min. WiO, Kraków 23 VII, 28 VII 1908; AKMK, WT, 1890-1928: Namiestnictwo do Ksiażęco-Biskupiego Ordynariatu, Lwów 22 VIII 1908.

37 AUJ, WT II 61: Kolegium Profesorów Wydz. Teol. UJ do Kongregacji Studiów, Kraków 14 VII 1908, (kopia).

3B AKMK, WT, 1890-1928: Książęco-Biskupi Ordynariat do Namiestnictwa, Kraków 22 IX 1908, (brulion). 
dogmatyki w Seminarium Duchownym w Poznaniu i Jakuba Górkę, profesora historii kościelnej $w$ Seminarium Duchownym $w$ Tarnowie ${ }^{39}$. Abp Bilczewski po rozmowach z kard. Puzyna i kolegium profesorów Wydziału doprowadzil do zgodnego przedstawienia przez nich Ministerstwu, zwyczajna droga, nastepujacych kandydatów: wymienionego wyżej ks. Sieniatyckiego na katedre teologii dogmatycznej szczegółowej i ks. Antoniego Bystrzonowskiego, katechete Gimnazjum św. Anny w Krakowie na katedre teologii pastoralnej. Obydwaj księża dnia 21 marca 1909 r. otrzymali nominacje na profesorów $\mathrm{UJ}^{40}$.

\section{ABPA ADAMA SAPIEHY SPÓR Z RZĄDEM}

Na tle obsady katedr doszło w 1925 r. do zatargu abpa Adama Stefana Sapiehy z Ministerstwem WRiOP po nominacji ks. Aleksandra Wóycickiego, znanego uczonego i posła do Sejmu Rzeczypospolitej, profesora chrześcijańskich nauk społecznych $w$ Uniwersytecie Wileńskim, profesorem tego samego przedmiotu na Wydziale Teologicznym UJ.

Nominacja ta została dokonana dnia 19 września $1925 \mathrm{r}^{41}$ bez uprzedniego uzgodnienia jej przez rząd $z$ biskupem krakowskim. W tych warunkach abp Sapieha zakomunikował Komisji Biskupów zebranej w Warszawie w dniach 7-8 listopada 1925 r., że bez jego wiedzy ks. A. Wóycicki został mianowany profesorem UJ. Pytal jak ma postapić w tym wypadku. Biskupi jednomyślnie oświadczyli, że "ordynariusz powinien dać w formie mandatu Księdzu Wóycickiemu zakaz wykładania na uniwersytecie. Aby nie stwarzać precedensu, ordynariusz Księdzu Wóycickiemu nie udzieli misji kanonicznej" 42 .

Minister WRiOP Stanisław Grabski, powolując się na art. XIII p. 1 Konkordatu pomiędzy Polską a Stolica Apostolską z 1925 r., zwrócił się 12 listopada 1925 r. do apba A. Sapiehy z prośbą o udzielenie ks. A. Wóycickiemu upoważnienia do nauczania $w$ UJ. Zaznaczyl przy tym że profesor ten posiada upoważnienie ordynariusza archidiecezji wileńskiej do wykładania na Wydziale Teologicznym ${ }^{43}$.

Abp A. Sapieha odpowiadajac ministrowi wyraził swoje zdziwienie wobec prośby i wyjaśnil, że konkordat, na który się powolal, wymaga zgody ordynariusza na mianowanie profesorów wydziału teologicznego, ale prawo

39 AUJ, WT II 16: Kongregacja Studiów do abpa J. Bilczewskiego, Rzym 7 X 1908, kopia.

40 AUJ, WT II 16: Protokól z posiedzenia Rady Wydz. Teol. UJ 26 X 1908; WT II 65: Min. WiO do Dziekanatu Wydz. Teol. UJ, Wiedeń 3 IV 1909; AKMK, WT, 1890-1928; Namiestnictwo do Książęco-Biskupiego Ordynariatu, Lwów 18 XI 1908.

41 "Dz. Urz. Min. WRiOP” 8:1925, poz. 189.

42 AKMK, TS 13: Protokól posiedzeń Komitetu Biskupów W dniach 7 i 8 listopada 1925 r. w Warszawie; TS 17 Kard. A. Kakowski do abpa A. Sapiehy, Warszawa 11 I 1926.

43 AKMK, TS 17: Min. WRiOP do Biskupa Krakowskiego, Warszawa 12 XI 1925. 
kościelne przyznaje to uprawnienie jedynie ordynariuszowi miejscowemu (can. 1381 §3). Biskup krakowski oświadczyl, że postawiony wobec faktu dokonanego, nie chcac przy tym "wprowadzać najwyższych czynników Państwa w konflikt" mógłby się zgodzić na tę nominacje, ale tylko pod warunkiem otrzymania od ministerstwa oświadczenia, że „brak zasięgnięcia zgody Ordynariusza był tylko przeoczeniem i że na przyszłość tego rodzaju nominacje [...] profesorów uniwersytetu [...] zawsze będa przedsiębrane dopiero po otrzymaniu zgody Ordynariusza" 44 .

„Konkordat - odpowiedzial minister S. Grabski - wyraźnie postanowil, że nauczycieli religii mianuje wladza szkolna «wybierając ich spośród osób upoważnionych przez Ordynariuszów», a nie "po uzyskaniu na to mianowanie zgody czy zezwolenia miejscowego Ordynariusza». Prezydent Rzeczypospolitej mianując ks. Wóycickiego profesorem Wydziału Teologicznego w Krakowie zastosowal się ściśle do postanowienia konkordatu. Dokonal bowiem przy tej nominacji “wyboru spośród osób upoważnionych przez ordynariuszów» ponieważ profesor ten był już upoważniony do wykładania na wydziale teologicznym przez jednego $z$ ordynariuszy. Oczywiście zgodnie $z$ postanowieniem wspomnianego art XIII Konkordatu: «w razie gdyby ordynariusz odebrał nauczycielowi dane mu upoważnienie, to ten ostatni będzie przez to samo pozbawiony prawa nauczania religii». Przysługuje Ekscelencji - pisal dalej Minister - prawo odebrać ks. Wóycickiemu upoważnienie do wykładania na Wydziale Teologicznym - a wtedy nominacja jego będzie przez Pana Prezydenta Rzeczypospolitej cofnięta" ${ }^{45}$.

Wprowadzenie w życie postanowicń konkordatu na odcinku kształcenia duchowieństwa wymagało - jak się okazalo - koniecznych wyjaśnień i uściśleń prawnych. Tymczasem konflikt narastał.

Abp A. Sapieha powyższą odpowiedź ministra zakomunikowal prymasowi kard. Edmundowi Dalborowi. Prymas stwierdzil, że zapatrywanie ministra S. Grabskiego, jakoby każdy nauczający, który gdziekolwiek i przez któregokolwiek biskupa ordynariusza był upoważniony do wykladania na wydziale teołogii już tym samym był kwalifikowany na wszystkie wydzialy w Polsce, bylo mylne. Art. XIII Konkordatu mówil bowiem o osobach upoważnionych przez Ordynariuszów, ale to się odnosiło do ordynariusza tych szkól, dla których mianowano nauczyciela. Minister w cytowanym wyżej piśmie - pisal prymas - „pragnie sie upewnić u Ordynariusza tak dalece, że nie będzie on odbierał posiadanego przez kandydata na profesora upoważnienia do wykładania na wydziale teologicznym. W ten sposób pragnie minister podwójnie skrępować Ordynariusza: raz, że nie pyta się go o wyraźna misję kanoniczną przed objęciem katedry przez kandydata, a po

4t Tamże: Książęco-Biskupi Konsystorz do Min. WRiOP, Kraków 27 XI 1925, kopia.

45 Tamże: Min. WRiOP do Biskupa Krakowskiego, Warszawa 5 XII 1925. 
wtóre, że chce odjąć Ordynariuszowi możność cofnięcia misji kanonicznej kiedykolwiek. Na takie stawianie kwestii oczywiście Episkopat zgodzić się nic może $\mathrm{e}^{\prime \prime 6}$.

Do czego doprowadził ten zatarg? Minister S. Grabski w celu uniknięcia w przyszłości tego rodzaju konfliktów między wydziałami teologicznymi uniwersytetów panstwowych a biskupami diecezjalnymi wydal w styczniu 1926 r. specjalny okólnik o wykonaniu art. XIIl Konkordatu przy stanowieniu profesorów na fakultetach teologicznych. Minister prosil w nim, aby do wniosków o nominacje profesorów i zatwierdzenie habilitacji dolączano oświadczenie uprzedniej zgody biskupa diecezjalnego. Przy mianowaniu kandydata, który już byl wykładowca na innym wydziale teologicznym należało uzyskać od miejscowego ordynariusza zapewnienie, że nie odbierze mu upoważnienia do nauczania, otrzymanego od ordynariusza innej diecezji ${ }^{47}$.

Biskupi krakowscy starali się zapewnić sobie możliwie największy wpływ na dobór zespołu kształcacego duchowieństwo diecezji. Konflikty powstale na tle tego dążenia, chociaż rzucaja się cieniem na stosunki pomiędzy biskupami krakowskimi a Wydziałem czy rzadem, nie moga jednak przesłonić ich troski o rozwój nauk teologicznych w UJ.

\section{BISKUPIA POMOC W KLOPOTACH KADROWYCH}

Każdorazowemu biskupowi krakowskiemu omawianego okresu Wydzial zawdzięczal skuteczna pomoc w poszerzeniu kadry nauczającej spośród księży z różnych diecezji i zgromadzeń zakonnych. Wielu z nich z czasem stalo się chlubą Uniwersytetu. Bp Dunajewski odegral zasadniczą rolę w sprowadzeniu z Rzymu do Krakowa ks. Stefana Pawlickiego CR i powierzeniu mu w 1882 r. pierwszej w monarchii austro-wegierskiej katedry filozofii chrześcijańskiejł" . Rok wcześniej (1881) zgodzil się na objęcie katedry teologii moralnej przez ks. Zygmunta Lenkiewicza, katechetę IV Państwowego Gimnazjum we Lwowie, habilitowanego w zakresie tej dyscypliny na Wydziale krakowskim w 1880 r. ${ }^{49}$ Poparł kandydaturę ks. Wladysława Chotkowskiego z archidiecezji poznańskiej, który w 1882 r. objął katedrę historii kościelnej jo. W 1883 r. na katedrę teologii dogmatycznej szczególowej przybyl ks. Emil Lamboy ze

46 Tamże: Kard. E. Dalbor do abpa A. Sapiehy, Poznań 30 XII 1925.

47 AUJ, WT II 52: Okólnik Min. WRiOP, Warszawa I 1926.

48 A. Przymusiala, Pazolicki Stefan Zachariasz. W: Polski Slownik Biograficzny (PSB), t. 25, s. 423-425; AGAD, MWiO 44 u: Bp A. Dunajewski do Prezydium Namiestnictwa, Kraków 14 VI 1882.

49 AKMK, WT, 1820-1889: Ordynariat Biskupi Krakowski do Prezydium Namiestnictwa, Kraków 14 V 1881, (brulion); C. Lechicki, Lenkiewicz Zygmunt. W: PSB, t. 17, s. 59-60.

50 AUJ, WT II 64: Min. WiO do Dziekanatu Wydz. Teol. UJ, Wiedeń 27 V 1882; T. Glemma, Chotkowski Wadysław. W: PSB, t. 3, s. 430-431. 
Lirowa ${ }^{51}$. W nastepnym roku (1884) katedre prawa kanonicznego otrzymal ks. Tadeusz Gromnicki, adiunkt Wydzialu Teologicznego Uniwersytetu Lwowskiego ${ }^{52}$. W $1887 \mathrm{r}$. profesorem zwyczajnym Studium Biblijnego Starego Testamentu i języków wschodnich zostal ks. Władysław Knapiński, doktor teologii Akademii Duchownej w Petersburgu, wikariusz parafii św. Krzyża w Warszawie ${ }^{53}$. Biskupowi Dunajewskiemu UJ zawdzięczal także znakomite wykłady ks. Mariana Ignacego Morawskiego TJ, zajmującego od 1887 r. po rezygnacji ks. Lamboya, katedrę dogmatyki szczegółowej ${ }^{54}$.

Za rządów biskupa J. Puzyny katedrę teologii moralnej, po odejściu ks. Lenkiewicza do Lwowa, obją ks. Antoni Trznadel, wykładowca teologii dogmatycznej $w$ Seminarium Duchownym w Przemyślu ${ }^{55}$. Po zakończeniu omówionego zatargu z Wydzialem kard. Puzyna zgodzil się na obsadę katedry teologii dogmatycznej szczególowej przez ks. Macieja Sieniatyckiego z Uniwersytetu Lwowskiego. Za jego aprobata powstala na Wydziale w $1910 \mathrm{r}$, pierwsza na ziemiach polskich i pierwsza w monarchii naddunajskiej, katedra chrześcijańskich nauk spolecznych, obsadzona przez ks. Kazimierza Zimmermanna z Poznania ${ }^{56}$.

Szczególne zaslugi w pozyskiwaniu dla Wydziału wybitnych profesorów polożył bp. A. Sapieha. W 1912 r. sprowadził ks. Jana Fijalka z Uniwersytetu Lwowskiego ${ }^{57}$. W 1914 r. na jego prośbę wizytator Księży Misjonarzy, ks. Antoni Słonimski, zgodził się na wykłady ks. Konstantego Michalskiego CM na Wydziale Teologicznym UJ ${ }^{58}$. Z Katolickiego Uniwersytetu Lubelskiego przybyl w 1920 r. ks. Józef Archutowski na katedrę Pisma św. Starego Testamentu ${ }^{59}$. W 1923 r. teologię fundamentahą zacząi wykiadać ks. Władyslaw Grzelak, wykładowca tej dyscypliny w Seminarium Duchownym

51 AUJ, WT Il 65: Min. WiO do Dziekanatu Wydz. Teol. UJ, Wiedeń 28 IV 1883.

52 AKMK, WT, 1820-1889: Prezydium Namiestnictwa do Ordynariatu Biskupiego w Krakowie, Lwów 25 VI 1884; AUJ, WT II 69: Min. WiO do Dziekanatu Wydz. Teol. UJ, Wiedeń 10 VI 1884; J. Krzemieniecki, Gromnicki Tadeusz. W: PSB, t. 8, s. 633-634.

53 AUJ, WT II 60: Min. WiO do Dziekanatu Wydz. Teol. UJ, Wiedeń 23 XI 1887; C. Lechicki, Kuapiniski Wiadysław. W: PSB, t. 13, s. 105-106.

54 AKMK, WT, 1820-1889: Ordynariat Biskupi do Prezydium Namiestnictwa, Kraków 28 VII 1887, (brulion); AUJ, WT II 65: Min. WiO do Dziekanatu Wydz. Teol. UJ, Wiedeń 24 I 1891; B. Natoniski, Mornuski Mnimn Igitacy. W: PSB, t. 21, s. 736-738.

55 AKMK, WT, 1890-1928: Ordynariat Książęco-Biskupi do Namiestnictwa, Kraków 31 VII i $8 \overline{8} 96$, (bruiion).

56 Tamże: Namiestnictwo do Książęco-Biskupiego Ordynariatu, Lwów 29 IX 1910; E. Komar, dz. cyt., s. 99.

57 AGAD, MWiO 44u: Wydz. Teol. UJ do Min. WiO, Kraków 12 X 1912; W. Semkowicz, Fijatek lon Nepomucen. W: PSB, t. 6, s. 441-443.

58 AUJ, WT II 67: Bp A. Sapieha do Dziekana Wydz. Teol. UJ, Kraków 11 I 1914; A. Przymusiała, Michalski Konstanty Józef. W: PSB, t. 20, s. 592-595.

59 AUJ, WT Il 60, W: Min. WRiOP do Grona Profesorów Wydz. Teol. UJ, Warszawa 16 V 1920. 
w Poznaniu'60. Dzięki staraniom abpa Sapiehy katedrę historii Kościola Powszechnego objal w 1927 r. bp Michal Godlewski, sufragan diecezji luckiej i żytomierskiej, byly profesor petersburskiej Akademii Duchownej ${ }^{61}$. Katedrę historii Kościoła w Polsce otrzymal w 1930 r. ks. Tadeusz Glemma, wykładowca dzicjów Kościola i sztuki sakralnej w Seminarium Duchownym w Pelplinie ${ }^{62}$. Ks. Marian Józef Morawski Tf od 1934 r. wykladał dogmatykę szczególową ${ }^{63}$.

Metropolita interweniowal dwukrotnie w 1934 r. u ministra WRiOP Waclawa Jędrzejewicza w sprawie wykładów ks. Jana Salamuchy z Warszawy na II Katedrze Filozofii Chrześcijańskiejot. W 1936 r. prosił ministra WRiOP Wojciecha Świętosławskiego o nominacje ks. Tadeusza Kruszyńskiego na profesora nadzwyczajnego historii sztuki kościelnej i liturgiki65.

Praktyka poszukiwania kandydatów o najwyższych kwalifikacjach naukowych wśród duchowieństwa różnych diecezji i zgromadzeń zakonnych zwryciężyła przejawiające się od czasu do czasu skłonności do ograniczania się jedynie do księży diecezji krakowskiej. Owocowała ona ciaglym wzrostem znaczenia naukowego Wydzialu zarówno w zakresie dydaktyki, jak i pracy badawczej.

60 AUJ, WT II 68: Min. WRiOP do Rektoratu UJ, Warszawa 3 XI 1923; M. Michalski, Grzelak Whadystaw. W: PSB, t. 9, s. 98 .

61 Archiwum Akt Nowych w Warszawie, MWRiOP 2640: Dziekanat Wydz. Teol. Uj do Min. WRiOP, Kraków 6 XI 1926; AU], S II 619, (kopia); M Żywczyński, Goillewski Michuł. W: PSB, t. 8, s. $181-182$.

62 AUJ, S II 619: T. Glemma, Życiorys; J. Mitkow'ski, Glemma Tadensz. W: PSB, t. 8, s. 44-45.

63 AUJ, II 17: Protokól z posiedzenia Rady Wydz. Teol. U], 19 IX 1934; B. Natoński, Mornuski Murian Józef. W: PSB, t. 21, s. 739.

64 AKMK, TS 17: Abp A. Sapieha do W. Jẹdrzejervicza, Kraków 7, 23 VII 1934; S. Piech, Sulamucha Jan. W: PSB, t. 34, s. 354-356.

65 AKMK, TS 17: Abp A. Sapieha do W. Świętoslawskiego, Kraków 19 XI 1936; A. Bochnak, Kruszyniski Tadeusz Albin. W: PSB, t. 15, s. 444-445. 